\title{
First report of charcoal disease caused by Biscogniauxia mediterranea on Olea europaea in Tunisia
}

\author{
Yaakoub Gharbi ${ }^{1} \cdot$ Karim Ennouri $^{1} \cdot$ Emna Bouazizi $^{1} \cdot$ Manel Cheffi $^{1} \cdot$ Mohamed Ali Triki $^{1}$
}

Received: 31 July 2019 / Accepted: 27 February 2020 / Published online: 16 March 2020

(C) Società Italiana di Patologia Vegetale (S.I.Pa.V.) 2020

Keywords Olea europaea $\cdot$ Charcoal disease $\cdot$ Pathogenicity

In March 2016, extensive decline of olive trees (Olea europaea L.) was recorded in the region of El-Awabed (Sfax, Southern Tunisia) and spread over 20 ha causing around $10 \%$ disease incidence. This disease affected the trunk and the leaves leading to the development of lengthwise bark cracks, detached bark, withering of the crown, and extensive microphyllia. In July 2016, black applanate stromata and fruiting bodies emerged in the trunks of the trees and were recognized as Biscogniauxia mediterranea (De Not.) O. Kuntze, a fungus causing charcoal canker in several plant species. Colonies grown on PDA were grey and black on the underside (Jurc and Ogris 2006). The stromata were applanate, ellipsoid, and elongate, 8.5 to $21.6 \times 3.7$ to $4.75 \mathrm{~cm}$. The perithecia were ovoid to tubular, 0.81 to $0.85 \times 0.15$ to $0.18 \mathrm{~mm}$. The ascospores were ovoid, brownish-black, measuring 6.7 to $8.7 \times 13.9$ to $20.2 \mu \mathrm{m}$. Traditional identification was further confirmed by sequencing of the rDNA-ITS and the $\beta$-tubulin gene. BLAST searches of ITS (KY275264.1) and $\beta$-tubulin (KY275263.1) sequences revealed 98 to $100 \%$ identity to $B$. mediterranea. Pathogenicity test was performed under greenhouse conditions, by injecting 27 olive plants with a $1 \times 10^{-6} \mathrm{~mL}$ ascospore suspension at the trunk junction. Forty-five days after inoculation, 17 plants showed a detached bark, while control plants remained healthy. At the end of the experiment, the fungus was successfully reisolated from the lesions of 11 symptomatic plants, which fulfill the Koch's postulates.

Yaakoub Gharbi

Yaakoub.gharbi@yahoo.com

1 Laboratoire de Recherche: Ressources Génétiques de l'Olivier : Caractérisation, Amélioration et Protection phytosanitaire, Institut de l'Olivier, Université de Sfax, SfaxBP1087, Tunisie
Biscogniauxia mediterranea was recently reported on Erica multiflora L. in Tunisia as well as on other plant hosts in different countries (e.g. Quercus cerris L. and Q. pubescens Willd) (Ragazzi et al. 2012; Yangui et al. 2019). Most recently, B. mediterranea has also been reported as endophyte on O. europaea in Portugal (Materatski et al. 2019). To our knowledge this is the first report of this fungus causing disease on olive trees in Tunisia and worldwide.

\section{Compliance with ethical standards}

Conflict of interest All authors declare that they have no conflict of interest.

\section{References}

Jurc D, Ogris N (2006) First reported outbreak of charcoal disease caused by Biscogniauxia mediterranea on Turkey oak in Slovenia. Plant Pathol 55:299

Materatski P, Varanda C, Carvalho T, Dias AB, Campos MD, Rei F, Félix MR (2019) Spatial and temporal variation of fungal endophytic richness and diversity associated to the phyllosphere of olive cultivars. Fungal Biol 123(1):66-76

Ragazzi A, Ginetti B, Moricca S (2012) First report of Biscogniauxia mediterranea on English ash in Italy. Plant Dis 96(11):1694

Yangui I, Zouaoui Boutiti M, Messaoud C, Ben Jamaa ML, Vannini A, Vettraino AM (2019) First report of Biscogniauxia mediterranea causing canker on Erica multiflora L. in Tunisia. J Plant Pathol. https://doi.org/10.1007/s42161-019-00339-x

Publisher's note Springer Nature remains neutral with regard to jurisdictional claims in published maps and institutional affiliations. 